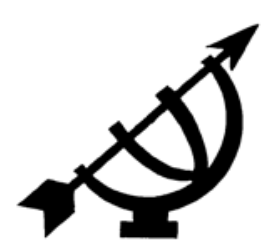

\title{
Reflecting on our past: reconciling a divided nation through listening
}

\author{
E.S.A. Ayee \\ School of Communication and the Arts \\ Regent University \\ Virginia Beach \\ E-mail: eayee@regent.edu
}

\begin{abstract}
Reflecting on our past: reconciling a divided nation through listening
\end{abstract}

The miracle of a relatively peaceful transition from apartheid to a non-racial democratic rule in South Africa stunned political pundits and observers. After decades of dehumanising laws which led to unbelievable racial conflict and the killing of many people, the country witnessed the birth of a new dispensation. This article briefly recounts the tragic history of South Africa, the current challenges the country faces for sustainable peaceful coexistence between the various racial groups, and the role that listening played and should continue to play in the process of national reconciliation.

\section{Opsomming}

Besinning oor ons verlede: versoening van 'n verdeelde nasie deur te luister

Die wonderwerk van 'n relatief vreedsame oorgang vanaf apartheid tot ' $n$ nie-rassige demokratiese regering in Suid-Afrika het politieke waarnemers en kenners verstom. Na dekades van dehumaniserende wette wat gelei het tot geweldige rassekonflik en die dood van baie mense, is die geboorte van 'n nuwe bedeling waargeneem. Hierdie artikel bied 'n kort oorsig oor Suid-Afrika se tragiese geskiedenis, die uitdagings wat die land tans in die gesig staar ten opsigte van die volhoubare en vreedsame naasbestaan van die verskillende rassegroepe, sowel as die rol wat luister speel, asook die voortgesette rol wat dit behoort te speel in die proses van nasionale rekonsiliasie. 


\section{Introduction}

Interracial conflict in South Africa is not a recent phenomenon; on the contrary, it dates back to the mid-seventeenth century with the arrival of Europeans on the subcontinent. Apart from the original African indigenous people, South Africa has been populated by colonial settlers of Dutch, German, French, and British ancestry. Even though segregation policies, practices and racism have their roots in South Africa's colonial past, the apartheid system that the National Party government created "imposed a legal form of oppression with devastating effects on the majority of South Africans" (TRC, 1999, 1:60). It is beyond dispute that the white colonial powers and other local white establishments that ruled South Africa from the mid-seventeenth to the late twentieth centuries used their monopoly over political, military, economic, and ideological power to advance themselves, plunder indigenous people, disrupt their social structures, and turn them into exploited workers (Terreblanche, 2002:5).

Since time immemorial, the attitude of many people of European descent towards people of other racial backgrounds reflects a deeply rooted belief of superiority, which is clearly reflected in how they treat others. History is replete with countless examples of not only illtreatment but blatant and shocking killings. For example, in their early history of settling on the tip of the African continent, the Boers "viewed the native Hottentots as jungle animals ... and totally wiped them out" (Henslin, 2003:357). Henslin argues that when you label a group of people as less than human, it makes it easier to justify killing them in order to take over their resources as happened when many Native Americans were killed by white settlers in the 1800s, or as the British settlers did in Tasmania when they "stalked the local aboriginal population, hunting them for sport and sometimes even for dog food" (Henslin, 2003:357).

Creating an apartheid system in South Africa was not a social engineering program gone wrong; it was a deliberate scheme that reflects a worldview of superiority that many whites have. The apartheid system created racial categories for all South Africans based on a system of racial hierarchy. Sociologist James Henslin observed that when people use labels that dehumanise others it helps them to compartmentalise and separate their acts from their sense of being good and moral people. Regarding members of a group as less than human leads them to rationalise that it is okay to treat them inhumanely (Henslin, 2003:357). As Esterhuyse (2000: 146) points out, "apartheid is one of the most dehumanizing and 
totalitarian ideologies to have become embodied in the political hegemonies of the twentieth century". The system and policies that were developed as a result of the ideology of apartheid were inherently immoral because it created conditions for the violation of fundamental human rights (Esterhuyse, 2000:147). When people are blinded to the humanity of others, it is impossible to genuinely listen to them. White South Africans therefore looked for every excuse under the sun to entrench themselves in power and create laws to justify their position.

\section{Life under apartheid}

Even though a system of exploitation and segregation existed in the early 1900s in South Africa, it was the promulgation of the Land Act of 1913 which dispossessed blacks of their land in order that white farmers could have them. This dispossession placed 80 percent of the population on less than thirteen percent of the land and resulted in desperately poor blacks being forced to provide cheap labor as farm workers, miners, and domestic workers. The dispossession continued through forced removals resulting in whole communities being moved to new locations, houses bulldozed and people's possessions dumped in far off areas. The Truth and Reconciliation Commission of South Africa Report poignantly observes that the introduction of the 1913 Land Act by the first postunification South African Party government was "one of the [most] ambitious and farreaching attempts at social engineering in twentieth century South African history" (TRC, 1999, 1:27). The report further notes that:

No other piece of legislation in South African history more dramatically and drastically reshaped the social map of this country. Not only did it lay the basis for the territorial separation of whites and Africans, it destroyed, at a stroke, a thriving African landowning and peasant agricultural sector. It did so by prohibiting African land ownership outside of the initial 7 percent of land allocated to the so-called traditional reserves and ending sharecropping and non-tenancy arrangements on white-owned farms. The Land Act set in motion a massive forced removal of African people that led, amongst other things to the deaths of many hundreds of people who found themselves suddenly landless.

The Land Act of 1913 was followed by the introduction of The Population Registration Act of 1950. This was the bedrock of the apartheid state because it provided for the classification of every South African into one of four racial groups: Europeans (whites), 
Africans (Bantu or blacks), Coloureds (mixed race), and those from Indian origin (TRC, 1999, 1:30; Henslin, 2003:250).

Willem Verwoerd, grandson of the architect of apartheid observed that, "the system of apartheid was designed to benefit whites and disadvantage black South Africans" (Verwoerd, 2000a:1). That system was based on the belief of white superiority which denied blacks the most basic rights and freedom and forced them to live in conditions of poverty and inequality. It also forced millions of black people to work for grossly insufficient remuneration in white areas where they lived in enclosed compounds with their white employers, and their own families were not allowed to visit. Apartheid laws even "allowed people to die rather than violate 'whites-only' hospital edicts, and then determined in which plot of land they could be buried (TRC, 1999, 1:41). A person need not have been a political activist to become a victim of apartheid. Being black and seeking the basic necessities of life that whites took for granted and enjoyed by right was enough to become a victim of apartheid (TRC, 1999, 1:35).

It is important to note that even though people did many evil things during the years of apartheid, it is the system itself that was evil, inhuman and degrading for millions who were regarded as second and third class citizens. The everyday violence of systemic and institutionalised racism had a devastating impact on blacks (Valji, 2004). James Gibson also underscored the same sentiment when he wrote that the root cause of interracial alienation in South Africa was colonialism and apartheid, which robbed many people of their dignity and led to unbelievable violence and political repression (Gibson, 2004:15). At least 3,5 million black South Africans were expelled, forced to migrate, or dumped into the "national states" without jobs. Apartheid was a grim daily reality for all black South Africans whilst many whites lived in luxury at the expense of a powerless majority of exploited blacks (Frankel, 1989:11).

The preceding section shows that apartheid was an oppressive and inhuman system of social engineering. It was resisted by the oppressed people of South Africa and the international community gave its support to the liberation movements. Eventually, the white government yielded to the pressure of economic and cultural sanctions and common sense. As its demise approached on the political horizon, there was debate on the concept of reconciliation and transformation and how to mend a nation that was broken and in need of healing and justice. 


\section{The role of listening in political negotiation}

Nelson Mandela was released from prison in 1990 after being incarcerated for 27 years. He and the then President F.W. de Klerk, risked their positions by choosing to engage in negotiated politics with its attendant compromises, instead of confrontational, adversarial politics. Even though there was the possibility that their followers may interpret their initiative as a sell out to the "enemy" or regard them as traitors, they nonetheless went ahead to involve other major stakeholders in the process of political negotiation.

One of the most bloody and violent periods in South African history was the period from 1990, when Mandela was released from prison, until 1994 when he was inaugurated as President. The climate of violence threatened to disrupt the political negotiation process and almost plunged the country into chaos (De Gruchy, 2002:186). Many people feared a civil war would engulf the country and those who were relatively optimistic feared there would be massive exodus of white people from the country resulting in a destabilised economy. Listening played a crucial role in this process as people saw the need for compromise in order to break deadlocks. Through debate and negotiation, a compromise was reached.

The Inkatha Freedom Party (IFP) continually felt marginalised during the negotiation process. Its insistence on a tribally based traditional authority within the framework of a federal state was rejected by the African National Congress (ANC). The IFP had strong feelings about their proposition and felt slighted. Their sense of ethnic identity and pride was wounded. Burley-Allen (1995) explains that strong feelings become a barrier that influences effective listening. This was so true when negotiations reached an impasse. Two weeks before the mandated election was to be held on 27 and 28 April 1994, international mediations broke down because of disagreement between the ANC and the IFP. The threat of a civil war loomed ominously over the political horizon. American former Secretary of State Henry Kissinger and British statesman Lord Peter Carrington left the country after their mediation efforts failed. I lived in South Africa with my wife and four children from 1989 to 1995 . I can bear testimony to the fact that people were disappointed and fearful when the international mediators left. However, unbeknown to many people, something unbelievable happened that turned things around for the better. Washington Okumu, a Kenyan professor of economics and an international mediator who was appointed advisor to the international mediation team remained in South Africa after the other mediators left. Michael Cassidy of African Enterprise, an inter-denominational 
and interracial Christian organisation, was instrumental in bringing Okumu to lead backstage negotiations. It is important to note that successful negotiation is only possible when both sides are willing to listen and understand each other (Asherman \& Asherman, 1990). Even though they could not initially see eye to eye, the protagonists were willing to patiently listen to each other, be more open to each other's views, suspend judgement during the discussions, and listen in order to negotiate an agreement that was in the interest of the whole country. Okumu's role led to a surprising negotiated settlement between Chief Mongosuthu Buthelezi, leader of the IFP, and the ANC. A Peace (Election) Agreement was signed in Pretoria on 19 April 1994 by Nelson Mandela, F.W. de Klerk, and Mongosuthu Buthelezi with Washington Okumu serving as witness. That was a political miracle in the unfolding dramatic history of South Africa.

Okumu (1995:xi) pointed out that the averting of an imminent civil war at the eleventh hour "can only be attributed to the intervention of Almighty God, blessing our humble efforts". This is a significant statement and reflects a worldview that acknowledges the primacy of divine intervention in human affairs. De Gruchy, recognising the spiritual dimension of life in the African worldview and its relatively obscure acknowledgement in Western thought, observed that one of the problems with a secular worldview is its inability to imagine that there are alternatives to those permitted by scientific rationality in the unfolding of history. Thus, "modernity leaves little room for the element of surprise, for the humanly unpredictable, but history is full of surprises, however we may account for them" (De Gruchy, 2002:211). Archbishop Desmond Tutu and others rightly point out that if the miracle of a negotiated settlement had not occurred in South Africa, the country would have been overwhelmed by the bloodbath that many people predicted would be the inevitable result of racial conflagration and civil war (TRC, 1999, 1:5; Gerwel, 2000: 281).

South Africa's emergence and transformation from authoritarianism and racism into a non-racial constitutional democracy happened through compromises that were the result of dialogue and difficult political negotiation (Simpson, 2002:221). The negotiation process involved a great deal of listening which enabled the various political players to modify their dogmatic positions in order to see and understand the perspectives of others on the opposite side of the fence. The willingness of all the parties to work cooperatively towards the establishment of a non-racial democracy could not have happened if they were not prepared to listen to one another. As 
Wolvin and Coakley (1996:31) point out, "listening does not mean agreeing ... one willingly and actively engages in the total listening process. Then, as a result of having listened, one agrees or disagrees".

\section{Listening and the process of reconciliation}

The South African theologian and academic De Gruchy (2002:15) sees reconciliation as a process "in which there is a mutual attempt to heal and overcome enmities, build trust and relationships, and develop a shared commitment to the common good". He suggests that reconciliation occurs through the

... interplay of speech, listening and action motivated by hope and love. The way in which we speak with and listen to the alienated 'other' is already an action that makes reconciliation a possibility. Both words and deeds are necessary if we are to rescue reconciliation from banality and recover its costly connection with telling the truth and social justice. (De Gruchy, 2002:22.)

The process of reconciliation also enables people to deal with and overcome past alienation, enmity and hurt so that it can pave the way for them to learn how to relate to the "other" in the present (De Gruchy, 2002:27). But, reconciliation invariably has to do with the conditions of inclusion and exclusion, and the grounds on which we relate to and accept "the other" (De Gruchy, 2002:86). It follows, therefore, that reconciliation is a behavioral process in which people take action to restore a relationship that is broken or create a new one following forgiveness (Cahn \& Abigail, 2007:293). A very important step in the process of reconciliation is to learn to put ourselves in the shoes of the "other" who has been hurt. Truth and justice are key elements that must help the process to achieve a genuine, metanoia, a turning around, a breaking with an unjust past, and a moving towards a new future (De Gruchy, 2002:164).

It could be argued that, at political level, reconciliation begun in South Africa when President F.W. de Klerk, leader of the National Party government, announced in Parliament on 2 February, 1990 that his government would unban the liberation movements, release political prisoners, and start negotiations. This announcement and the subsequent release of political prisoners and the unbanning of liberation movements, set in motion a reform process which four years later resulted in the election of Nelson Mandela as President of a new multiracial government. Boraine (2000:345) observes that, 
"this was the beginning, and a very important beginning, of reconciliation in South Africa". In December 1989, two months prior to his announcement, F.W. de Klerk in his Christmas address to the nation asked the Christian church in South Africa "to formulate a strategy conducive to negotiation, reconciliation and change" (Alberts \& Chikane, 1991:14). In response to De Klerk's request, a national conference of churches was organised in Rustenburg in November 1991. It brought together about 230 church leaders from 80 denominations and 40 para-church organisations (Alberts \& Chikane, 1991:10). The conference produced what came to be known as the Rustenburg Declaration.

Frank Chikane observed that the conference gave church leaders an opportunity to get to know one another and to shed any stereotypes and distortions they had (Alberts \& Chikane, 1991:10). One significant and memorable development at this conference was the spirit of confession which entered the ranks and took hold on all sides. It began with an astonishing confession from Professor Willie Jonker, a theologian from Stellenbosch University, related to the Afrikaner's sins, in general terms, of racial discrimination and apartheid, and those of the Dutch Reformed Church in particular (Cassidy, 1995:98). Willie Jonker said:

I confess before you and before the Lord, not only my own sin and guilt, and my personal responsibility for the political, social, economic and structural wrongs that have been done to many of you, and the results of which you and our whole country are still suffering from, but vicariously I dare also to do that in the name of the Dutch Reformed Church (DRC) of which I am a member, and for the Afrikaans people as a whole. I have the liberty to do just that, because the DRC at its latest synod has declared apartheid a sin and confessed its own guilt of negligence in not warning against it and distancing itself from it long ago. (Cassidy, 1995:92.)

Many people attending the conference were moved to tears by this bold and courageous confession. Scores of people from different sectors of the church during the course of the conference went forward to also make confessions. These public confessions affirmed the commitment of many Christian leaders to be reconciled. However, not everyone appreciated all the confessions. Some confessions were "met with a measure of caution, if not skepticism" (Cassidy, 1995:99).

This public confession by church leaders and their desire for reconciliation is significant, because, as the Truth and Reconciliation 
Commission later pointed out, during the apartheid era, "Faith communities often helped reinforce the idea that South Africa was a relatively normal society suffering from a few racial problems. Challenges to the consciences of whites were rare" (TRC, 1999, $4: 65)$. In spite of this blot, it is well known that many church leaders and Christian organisations played a positive role not only in opposing the apartheid system, but also in the reconciliation process. De Gruchy (2002:121) observed that "Christians, Muslims and Jews did stand shoulder to shoulder in the struggle against apartheid, and they are likewise involved at many levels in working together today to make democratic transformation a reality". Prior to the democratic elections of 1994, some Christian leaders worked behind the scenes to bring political leaders from different parties to talk to each other or to mediate between warring factions in the townships. One such example occurred in 1992 and offers glimpses into the role that listening played in the unfolding history of reconciliation in South Africa.

Michael Cassidy of African Enterprise and his team came up with the idea of getting political leaders from different parties together to help them discover one another in real relationships. According to Cassidy (1995:49), this was "an experiment in building relationships and trust across political barriers". From December 1992 and throughout 1993, they succeeded in organising weekends of dialogue for over 90 senior politicians, more than 48 younger ones, and many political youth leaders at a place called Kolobe, a game lodge with excellent facilities located north of Pretoria (Cassidy, 1995:67). There were representatives from various political groups including the African National Congress (ANC), the Pan Africanist Congress (PAC), the Azanian People's Liberation Army (APLA), the Azanian People's Organization (AZAPO), the South African Communist Party (SACP), the Inkatha Freedom Party (IFP), the National Party (NP), the Democratic Party (DP), and the Afrikaner Volksunie (AVU).

During the weekends of dialogue, each person shared their own stories and experiences, they discussed various issues, shared their vision of a new South Africa, and an explanation of what steps they believed are required to reach this new South Africa (Cassidy, 1995:49-50). They also spent time going on game drives in the park to watch the animals, had picnics and lots of fun, and watched television together. At the end of their discussions, the participants looked to the future and proposed different strategies on how to get there. These groups of strangers soon became friends. The process of reconciliation was beginning in the hearts of the leaders from 
various political and ideological backgrounds. They spent time talking to and listening to one another.

Cassidy (1995:79) reports the following touching incidents illustrating the positive impact of the weekends of dialogue. On one occasion, after listening to the leader of AZAPO's Northern Transvaal Education Secretariat during one of the dialogue sessions at Kolobe, a cabinet minister in the South African government of that time confessed: "I had grown up to hate AZAPO ... now I can feel and empathize with him because I have learned from him about his experiences. How can I hate someone I now know as a real flesh and blood human being?" On another occasion, the daughter of a veteran Indian politician who attended the younger leaders' dialogue said: "Last night I sat up late talking and listening to several conservative Afrikaners. Their stories have profoundly affected me and changed my attitudes to Afrikaners completely. All in the space of one day!".

Andries Beyers, leader of the Afrikaner Volksunie (AVU) and a onetime senior leader in the Conservative Party was so touched by the experience in Kolobe that he eventually renounced the policy of fighting for the establishment of an Afrikaner homeland. He also resigned as leader and member of the AVU. He noted that the weekends of dialogue with people from different political parties was the first time in his life that he had communicated with black leaders on a personal level. He added:

I found what I had missed all these years in terms of real communication with my fellow South Africans. In fact I came to realize I simply did not know my fellow South Africans. The only personal contact I had had with blacks previously was as an employer and them as my workers ... These people are not so bad after all and it won't be disastrous living with them as compatriots and fellow citizens ... in fact ... we can even work together. (Cassidy, 1995:81.)

Addie van Rensburg, a member of the National Executive of the Afrikaner Volksunie also later resigned from his political party because of his experience and radical attitude change which happened during four different weekend dialogue sessions he participated in. He indicated that the opportunity to get away was a very important strategy to help facilitate a positive climate for dialogue. Without this the full potential and impact of dialogue would not have been achieved. As he reflected on the Kolobe experience, Van Rensburg further observed: 
Facing people who were on the wrong side of the apartheid fence made me realize with shame and sadness that apartheid had become a monster which dehumanized people and subjected them to the most degrading laws and regulations, and all in an attempt to preserve a status quo which could no longer be defended. The stories shared by people ... had a devastating impact on me and on the hearts and minds of everybody present. In fact, Kolobe proved to me that the biggest problem we face in South Africa is one of perceptions. We talk about each other rather than to each other. And we form perceptions of each other based on hearsay. Then through those false perceptions, we fan the flames of hatred ... while I love my own people deeply and will always be an Afrikaner, I will never again be part of a system which denies other people the opportunities I have had. (Cassidy, 1995:83.)

Going away to a place of beauty and quiet, isolated from the hustle and bustle of life for the dialogue sessions was very important. The environment they chose enabled people to open up to each other, to new things and to the chemistry of change. Cassidy (1995:78) also notes that

... the Kolobe encounters, and the process of listening to one another's stories, had the astonishing effect of causing people to lift blame and judgment on others and acknowledge varying degrees of their own guilt and culpability for inflicting pain, rejection, oppression or misunderstanding on others ... as people shared their stories and perhaps their pain, others came to see where they had contributed to that pain.

The Kolobe experience offers some important insights into the role of listening in the reconciliation process. We notice that people from various political and ideological backgrounds began to open up as they heard each other's stories and experiences. This slowly led to the development of what Wolvin and Coakley (1996:135) refer to as positive attitudes that give listeners the willingness - the desire - to listen. Political opponents suddenly began to develop positive listening attitudes - showing interest in what others had to say, putting themselves in the shoes of others (other-oriented), being patient, respecting others as equals, and being open-minded (Wolvin \& Coakley, 1996). The ability to be open-minded and other-oriented allowed each person to patiently listen to what their opponent who they regarded as "the enemy" had to say. Open-minded listeners are also active listeners because they carefully listen to all sides of an issue without prejudging in order to understand issues and then respond in a respectful manner (Folger et al., 2005; Dalton et al., 
2006; Galvin \& Cooper, 2006). Through dialogue in Kolobe, racial prejudice and disrespect for the humanity of others gave way to new perceptions that were grounded in reality.

Nelson Mandela also contributed greatly to the process of reconciliation in a quiet but significant way. Terreblanche (2002:27) rightly points out that Mandela's reconciliatory attitude must be credited for the peaceful transition towards a non-racial dispensation. Mandela was willing to listen to divergent views and to make compromises; by doing this he set an example for many of his followers and supporters. His attitude towards reconciliation is an example par excellence.

\section{Listening to the victims of injustice}

Archbishop Desmond Tutu, who served as chairperson of the Truth and Reconciliation Commission, at the beginning of the public hearings called on South Africans not to forget the past, and

let bygones be bygones, because such amnesia would have resulted in further victimisation of victims by denying their awful experiences ... However painful the experience ... we need to know about the past in order to establish a culture of respect for human rights ... for the future (TRC, 1999, 1:7).

He pointed out that the Commission was committed to listening to everyone; therefore each person should be given the chance to recount the truth as they saw it (TRC, 1999, 1:112).

De Gruchy (2002:206) observes that if a society is serious about the restoration of justice within the context of national reconciliation, it must take the voice of the victims of injustice as primary and refuse to allow that voice to be silenced. The Commission heard the painful and tragic stories of parents who endured horrors in their encounters with the police and other officials. It also listened to perpetrators describe in awful detail the acts of terror, assassination and torture they had inflicted on many people for many years. In addition to this, consider also the stunning disclosure that the previous government, under its Chemical and Biological Warfare Programme, had many nefarious activities, including inter alia projects that allegedly aimed at conducting experiments to create diseases and sterilisation measures aimed at reducing the fertility of black women (TRC, 1999, 1:18; Valji, 2004:7). Any sensible person hearing these confessions would be enraged.

As the TRC report notes, 
The Commission tried to listen, really listen - not passively but actively - to voices that for so long had been stilled. And as it listened to stories of horror, of pathos and of tragic proportion, it became aware again of the high cost that has been paid by so many for freedom. Commissioners were almost overwhelmed by the capacity of human beings to damage and destroy each other. Yet they listened, too, to stories of great courage, concluding often with an astonishing generosity of spirit, from those who had for so long carried the burden of loss and tragedy. (TRC, 1999, 5:306-307.)

Attitude plays an important role in our ability to listen empathically. "Empathy arises out of mutual efforts to understand and be understood, and requires the cooperation of both participants" (Brownell, 2002:186). From the preceding discussion, it is apparent that many blacks were eager to get information that will enable them to understand the past, know who were responsible for the disappearance and murder of their loved ones, and consequently, willingly embark on the process of reconciliation. By and large, the attitude of many whites was dismissive and showed contempt for the legally established Truth and Reconciliation Commission. Many whites were not prepared to listen; they had a negative attitude, one that was not open and interested in listening to "the other" people whom the ideology of apartheid did not consider as equals.

\section{Challenges and the way forward}

Some writers (Murithi, 2006; Terreblanche, 2002; Pigou, 2002; Bam, 2001; Gerwel, 2000) describe the current social and economic climate in South Africa as one in which a fragile reconciliation exists because of continuing inequality in the distribution of income, high levels of crime, violence, black unemployment, abject poverty, and a lack of material improvement in the lives of the majority of the people. They see tackling the economic well-being of large sections of the South African populace as a prerequisite for a sustainable reconciliation process. Social and economic inequalities are therefore issues that pose great challenges and need to be continually addressed. The challenge today is to work to restore the dignity and humanity of the majority of South Africans and to address the economic inequalities which could fuel social conflict.

Many South Africans sacrificed so much for the struggle in order to be free. Their expectation was that life would be better now than under apartheid. Unfortunately, it is predominantly only the leaders of the struggle whose lives have improved whilst many South Afri- 
cans continue to endure unacceptably high levels of poverty, unemployment and inequality. This situation poses a very big challenge to reconciliation. As long as victims of the apartheid past as well as the majority of South Africans live in conditions not much better than what they were used to in the past, reconciliation will sound hollow and meaningless to them. Trying to reconcile a divided nation without trying to address the injustices belittles the suffering of many victims. Even though justice and equity are not sufficient conditions for reconciliation, they are important elements in the process of building harmonious and positive relationships between previously antagonistic parties.

Another thorny issue is the fact that many whites refuse to critically evaluate the past and explicitly acknowledge that they benefited from colonialism and apartheid. White young people say that they are not responsible for the atrocities of the past and should not be blamed for the effects of white domination and apartheid. They are usually adamant that the large-scale material benefits that they, their parents and grandparents accumulated during the period of colonialism and apartheid belong to them and them alone (Terreblanche, 2002:4-5). Verwoerd (2000b:2) concurs that "[t]he legacy of racial discrimination is painfully evident in the privileged lives of most whites and the acute deprivation experienced by most blacks". He further observes that many of the post-1990 generation of young white people

... display a shocking lack of historical awareness. They prefer to see their own and their parents' educational achievements ... good health and wealth as purely the product of hard work, as something they deserve (Verwoerd, 2000b:2).

He laments that whilst the silence of apartheid beneficiaries is deafening and the ongoing suffering of the systematically disadvantaged is undeniable, "many whites continue to deny their responsibility arising from systematic past privileging ... this denial rubs salt into the wounds of the disadvantaged!" (Verwoerd, 2000b:2). Hofmeyr suggests that it is difficult for the beneficiaries of the apartheid system to acknowledge that their "privilege was built on, and protected by, brutality that caused extreme hardship for millions. It can be argued that true reconciliation can only occur when this acknowledgement has taken place and the full extent of this reality has been grasped" (Hofmeyr, 2005:29). Terreblanche (2002:4) warns that if whites ignore the benefits of the past, they should not expect the victims of colonialism to accept them as trustworthy companions in building a common future. 
For the sake of their own future, and the future of the whole country, whites must look out for practical and realistic ways to achieve equity, rather than protect their vested interests. They must redress the racial inequalities of the past in order to restore broken relationships with groups they have alienated from themselves. Getting those who profited from the past to realise the injustice of the apartheid system is only one side of the coin. "The other side demands deliberate interventions in order to transform South African society. This is one of the most serious ethical, political and strategic challenges" facing South Africa (Esterhuyse, 2000:153). The arrogance and unwillingness of some whites to see and accept that apartheid was wrong is appalling. Their refusal to listen to the agonising cries of many who were brutalised and dehumanised by the apartheid system is unacceptable.

Ethnocentrism, prejudice, negative stereotyping, and racism are major obstacles to effective listening. Therefore, South Africans must learn to accept people who are racially and ethnically different from themselves as equals and treat them with dignity and respect in order to facilitate ongoing dialogue and relationship building. South Africans must not forget or throw away their histories, neither should they pretend to be untouched by them. On the contrary, they must try to work with those histories in ways that acknowledge their complicity with the past, while attempting not to repeat it today (Erasmus, 2005:29-30).

The callous indifference of many white people needs to change. They must listen to the pain and suffering of many blacks who suffered under apartheid. They must support various initiatives to reconcile the nation and redress the wrongs of the past. Too little justice "could militate against the ability of victims and survivors to come to terms with the past - a matter that could come back to haunt the nation. Not least, it would not have helped in the rule of law and the need for accountability so desperately needed in an emerging democracy" (Villa-Vicencio, 2000:2).

It is important for all South Africans to heed the following words by American author and scholar, Paula Rothenberg (2002:4):

History tells us that in the end, an unjust and inequitable distribution of resources and opportunities leads to terrible violence ... A society that distributes educational opportunities, housing, health care, food, even kindness, based on the color of peoples' skin and other arbitrary variables cannot guarantee 
the safety or security of its people. In this sense, all of us, both the victims and beneficiaries of racism, pay a terrible price.

The words in the opening lines of the Preamble of the 1996 Constitution of South Africa should be in all the official languages and placed in offices and homes as a reminder:

We the people of South Africa, recognize the injustice of our past; honor those who suffered for justice and freedom in our land; respect those who have worked to build and develop our country; and believe that South Africa belongs to all who live in it, united in our diversity.

\section{List of references}

ALBERTS, L. \& CHIKANE, F. 1991. The road to Rustenburg: the church looking forward to a new South Africa. Cape Town: Struik.

ASHERMAN, I. \& ASHERMAN, S. 1990. The negotiation sourcebook. Amherst: Human Resource Development Press.

BAM, J. 2001. But one choice? http://www.hnet.org/reviews/showrev.cgi?path= 23387980364331 Date of access: 21 Jul. 2006.

BORAINE, A. 2000. A country unmasked: inside South Africa's Truth and Reconciliation Commission. New York: Oxford University Press.

BROWNELL, J. 2002. Listening: attitudes, principles, and skills. Boston: Allyn \& Bacon.

BURLEY-ALLEN, M. 1995. Listening: the forgotten skill: a self-teaching guide. New York: Wiley.

CAHN, D.D. \& ABIGAIL, R.A. 2007. Managing conflict through communication. 3rd ed. Boston: Pearson.

CASSIDY, M. 1995. A witness for ever. London: Hodder \& Stoughton.

DALTON, M., HOYLE, D.G. \& WATTS, M.W. 2006. Human relations. 3rd ed. Mason: Thomson South-Western.

DE GRUCHY, J.W. 2002. Reconciliation: restoring justice. Minneapolis: Fortress.

ERASMUS, Z. 2005. Race and identity in the nation. (In Daniel, J., Southall, R. \& Lutchman, J., eds. State of the nation: South Africa 2004-2005. Cape Town: HSRC. p. 9-33.)

ESTERHUYSE, W. 2000. Truth as a trigger for transformation: from apartheid injustice to transformational justice. (In Villa-Vicencio C. \& Verwoerd, W., eds. Looking back reaching forward: reflections on the Truth and Reconciliation Commission of South Africa. Cape Town: University of Cape Town Press. p. 144-154.)

FOLGER, J.P., POOLE, M.S. \& STUTMAN, R.K. 2005. Working through conflict: strategies for relationships, groups, and organisations. 5th ed. Boston: Allyn \& Bacon.

FRANKEL, M. 1989. Out of the shadows of the night: the struggle for international human rights. New York: Delacorte.

GALVIN, K.M. \& COOPER, P.J. 2006. Making connections: readings in relational communication. 4th ed. Los Angeles: Roxbury. 
GERWEL, J. 2000. National reconciliation: holy grail or secular pact? (In VillaVicencio, C. \& Verwoerd, W., eds. Looking back reaching forward: reflections on the Truth and Reconciliation Commission of South Africa. Cape Town: University of Cape Town Press. p. 277-286.)

GIBSON, J.L. 2004. Overcoming apartheid: can truth reconcile a divided nation? New York: Sage.

HENSLIN, J.M. 2003. Sociology: a down-to-earth approach. 6th ed. Boston: Allyn \& Bacon.

HOFMEYR, J.H. 2005. Report of the fourth round of the SA Reconciliation barometer survey. Rondebosch: Institute for Justice and Reconciliation.

MURITHI, T. 2006. Practical peacemaking wisdom from Africa: reflections on ubuntu. The journal of Pan African studies, 1(4):25-34.

OKUMU, W. 1995. Forward. (In Alberts, L. \& Chikane, F. The road to Rustenburg: the church looking forward to a new South Africa. Cape Town: Struik.

PIGOU, P. 2002. False promises and wasted opportunities? Inside South Africa's Truth and Reconciliation Commission. (In Posel, D. \& Simpson, G., eds. Commissioning the past: understanding South Africa's Truth and Reconciliation Commission. Johannesburg: Witwatersrand University Press. p. 37-65.)

ROTHENBERG, P.S. 2002. White privilege: essential readings on the other side of racism. New York: Worth.

SIMPSON, G. 2002. "Tell no lies, claim no easy victories": a brief evaluation of South Africa's Truth and Reconciliation Commission. (In Posel, D. \& Simpson, G., eds. Commissioning the past: understanding South Africa's Truth and Reconciliation Commission. Johannesburg: Witwatersrand University Press. p. 220-251.)

TERREBLANCHE, S. 2002. A history of inequality in South Africa, 1652-2002. Durban: University of Natal Press.

TRC

see TRUTH AND RECONCILIATION COMMISSION

TRUTH AND RECONCILIATION COMMISSION. 1999. Truth and Reconciliation Commission of South Africa Report. 5 vols. London: Macmillan.

VALJI, N. 2004. Race and reconciliation in a post-TRC South Africa. Johannesburg: Center for the Study of Violence and Reconciliation. http://www.csvr.org.za/papers/papnv3.htm Date of access: 21 Jul. 2006.

VERWOERD, W. 2000a. Towards the recognition of our past injustices. (In Villa-Vicencio, C. \& Verwoerd, W., eds. Looking back, reaching forward: reflections on the Truth and Reconciliation Commission of South Africa. Cape Town: University of Cape Town Press. p. 155-165.)

VERWOERD, W. 2000b. The TRC and apartheid beneficiaries in a new dispensation. Johannesburg: Centre for the Study of Violence and Reconciliation.

VILLA-VICENCIO, C. 2000. Neither too much, nor too little justice: amnesty in the South African context. (In Villa-Vicencio, C. \& Verwoerd, W., eds. Looking back, reaching forward: reflections on the Truth and Reconciliation Commission of South Africa. Cape Town: University of Cape Town Press.)

WOLVIN, A. \& COAKLEY, C.G. 1996. Listening. 5th ed. Boston: McGrawHill. 


\section{Key concepts:}

apartheid

listening

reconciliation

Truth and Reconciliation Commission

\section{Kernbegrippe:}

apartheid

luister

versoening

Waarheids- en Versoeningskommissie 